\title{
An Assay for Determination of Hepatic Zinc by AAS - Comparison of Fresh and Deparaffinized Tissue
}

\author{
Raquel Borges Pintoํ, Pedro Eduardo Fröehlich², \\ Ana Cláudia Reis Schneider ${ }^{3}$, André Castagna Wortmann ${ }^{3}$, \\ Tiago Muller Weber ${ }^{2}$ and Themis Reverbel da Silveira1, ${ }^{*}$ \\ ${ }^{1}$ Post Graduate Program in Medicine: Pediatrics, \\ ${ }^{2}$ Post Graduate Program in Pharmaceutical Sciences, UFRGS, Porto Alegre, \\ ${ }^{3}$ Post Graduate Program in Medical Sciences: Gastroenterology and Hepatology, \\ Universidade Federal do Rio Grande do Sul (UFRGS), \\ Hospital de Clínicas de Porto Alegre, \\ Brazil
}

\section{Introduction}

Atomic absorption spectroscopy (AAS) is a reliable method to determine metal concentrations. Zinc is a fundamental trace element because of its role in several essential biochemical functions. It is a component or co-factor of several enzymes, such as alcohol dehydrogenase and superoxide dismutase. It is of fundamental importance in cell division, genetic expression, and physiological processes, such as growth and development, immunity and wound healing; also, it plays a structural role in stabilizing biomembranes (Hambidge, 2000; Kruse-Jarres, 2001).

The importance of the determination of the hepatic concentration of certain metals is clearly established in the investigation of hereditary hemochromatosis and Wilson's disease (Pietrangelo, 2003, Roberts et al; 2003). As well, some interesting studies were published on the importance of zinc related to hepatic diseases. Decreases in plasma (Halifeoglu et al., 2004; Schneider et al., 2009; Pereira et al., 2011) or serum (Hamed et al., 2008, Matsuoka et al., 2009) zinc concentrations have been described in patients with chronic liver diseases. Authors that measured zinc in the liver parenchyma of adults and children with liver cirrhosis found low zinc levels (Milman et al., 1986; Göksu \& Özsoylu, 1986; Sharda \& Bhandari, 1986; Kollmeier et al., 1992; Adams et al., 1994). In patients with alcoholic cirrhosis, studies found abnormal zinc concentrations not only in the liver parenchyma (Rodriguez-Moreno et al., 1997), but also in subcellular fractions of the liver (Bode et al., 1988). In other diseases, such as biliary atresia (Bayliss et al., 1995; Sato et al., 2005), Indian childhood cirrhosis (Bhardwaj et al., 1980; Sharda \& Bhandari, 1986), and chronic hepatitis B (Gür et al., 1998), also were found low liver zinc concentrations.

${ }^{*}$ Corresponding Author 
Paraffin-embedded liver tissue usually stored in Pathology Laboratories may be used for analysis when fresh tissue is not available. Some hepatic diseases present a severe imbalance in the metabolism of metals, for example the excess of copper in Wilson's disease and iron in hemochromatosis. Recently, Wortmann and colleagues have validated an analytical method similar to ours for hepatic iron quantification, following the guidelines recommended by the International Conference on Harmonisation (ICH) of Technical Requirements for Registration of Pharmaceuticals for Human Use (Wortmann et al., 2007). Due to the fact that zinc is a protective metal to human health, the assessment of zinc status has a great importance in clinical investigation. Since there is only a few data available in the literature about methods to determine zinc concentration in hepatic tissue, the assay proposed can be helpful to this analysis. Therefore, the purpose of this study was to compare zinc concentrations in fresh and deparaffinized tissues and to determine whether the concentration of this metal in liver specimens is influenced by tissue processing in paraffin blocks.

\section{Material and methods}

This study was conducted after the validation of the graphite furnace AAS method to determine zinc concentration in bovine liver tissue (Fröehlich et al., 2006), in accordance with the guidelines established by ICH, FDA and ANVISA (ICH, 2005; FDA, 2001; ANVISA, 2003). We used a standard zinc solution $(1 \mathrm{mg} / \mathrm{ml})$ and standard bovine liver material from the National Institute of Standards and Technology (NIST, SRM 1577b) with known zinc concentrations $(127 \pm 16 \mu \mathrm{g} / \mathrm{g}$ dry weight $)$.

A steel scalpel was used to obtain 29 wedge biopsies from the same bovine liver obtained from a local market. Each specimen measured about $4 \times 2 \mathrm{~cm}$, and 2 were excluded from each group due to contamination and loss of material. Each of the 27 remaining specimens was divided in half, and two groups of samples were formed.

This study was approved by the Ethics in Research Committee of the Research and Graduate Studies, Hospital de Clínicas de Porto Alegre, Porto Alegre, Brazil.

\subsection{Group 1}

The samples in group 1 were placed in eppendorf tubes previously decontaminated with $10 \%$ nitric acid $\left(\mathrm{HNO}_{3}\right)$. Samples were lyophilized, using a lyophilizer (Micro moduli 97, Edwards ${ }^{\circledR}$ ) for 72 hours. After lyophilization, $500 \mu \mathrm{L}$ of concentrated $\mathrm{HNO}_{3}$ (twice distilled, Zn concentration $<0.5 \mu \mathrm{g} / \mathrm{g}$ ) was added to each sample, and sonication was applied for 1 hour. The samples were then placed in an incubator (303, Biomatic $\left.{ }^{\circledR}\right)$ at $60^{\circ} \mathrm{C}$ for 1 hour to complete digestion of organic matter. From each of the 27 solutions prepared, $50 \mu$ were poured into automatic sampler vials, and $950 \mu \mathrm{l}$ of pure water (Milli-Q Plus, Millipore ${ }^{\circledR}$ ) was added. Concentrations were then determined with a graphite furnace (HGA 800, Perkin-Elmer ${ }^{\circledR}$ ) AAS (AAnalyst-3000, Perkin-Elmer ${ }^{\circledR}$ ) and an automatic sampler (AS-72).

\subsection{Group 2}

Samples in the second group were fixed in formalin, embedded in paraffin, and later deparaffinized. The material was kept in paraffin blocks for about 7 days. The samples were 
deparaffinized by placing them in an incubator at $60^{\circ} \mathrm{C}$ for about 30 minutes to dissolve the paraffin block, and then in an average of two xylene baths (about 30 minutes each) alternating with 4 baths of alcohol (99\%) and distilled water until the paraffin was totally removed. The samples were lyophilized for $72 \mathrm{~h}$ and concentrations were determined using AAS, following the same procedure described for samples in group 1. Mean dry weight of the 27 samples after lyophilization was $39.9 \mathrm{mg}$, and, after deparaffinization, $38 \mathrm{mg}$. Reagents were analyzed to assess contamination by zinc, which was negligible.

\subsection{Statistical analysis}

The software Microsoft Excel for Windows ${ }^{\circledR}$ and the Statistical Package for Social Sciences ${ }^{\circledR}$ 12.0 (SPSS) were used to create a database and to conduct statistical analysis. Measures of central tendency and dispersion were used to describe data, with means and standard deviations for quantitative variables. The Student $t$ test for paired samples was used for comparisons between groups. The level of significance was established at $p<0.05$.

\section{Results}

\subsection{Group 1 - Analysis of fresh liver tissue}

Zinc concentration in group 1 was $173.6 \pm 37.9 \mu \mathrm{g} / \mathrm{g}$ dry tissue (mean \pm standard deviation). Table 1 shows the results for the 27 fresh bovine liver samples analyzed after lyophilization.

\subsection{Group 2 - Liver tissue analyzed after deparaffinization}

Zinc concentration in group 2 was $220.2 \pm 127.0 \mu \mathrm{g} / \mathrm{g}$ dry tissue (mean \pm standard deviation). Table 1 shows the results of 27 bovine liver samples that were embedded in paraffin, deparaffinized, lyophilized and then analyzed.

\subsection{Comparison between analysis of fresh and deparaffinized samples}

Liver zinc concentrations in fresh and deparaffinized samples were compared by Student $t$ test for paired samples, and there were no statistically significant differences between these two groups $(p=0.057)$.

\begin{tabular}{ccc}
\hline Samples & $\begin{array}{c}\text { Concentration fresh liver } \\
(\mu g / g d r y \text { tissue })\end{array}$ & $\begin{array}{c}\text { Concentration deparaffinized liver } \\
(\mu \mathrm{g} / \mathrm{g} \text { dry tissue })\end{array}$ \\
\hline 1 & 213.3 & 246.6 \\
2 & 178.5 & 148.0 \\
3 & 169.5 & 163.3 \\
4 & 241.2 & 153.8 \\
5 & 154.3 & 201.8 \\
6 & 154.0 & 201.4 \\
7 & 179.4 & 171.6 \\
8 & 169.2 & 193.7 \\
9 & 170.8 & 185.1
\end{tabular}




\begin{tabular}{ccc}
\hline Samples & $\begin{array}{c}\text { Concentration fresh liver } \\
(\mu g / g \text { dry tissue })\end{array}$ & $\begin{array}{c}\text { Concentration deparaffinized liver } \\
(\mu g / g \text { dry tissue })\end{array}$ \\
\hline 10 & 168.0 & 200.2 \\
11 & 188.2 & 215.4 \\
12 & 221.6 & 212.9 \\
13 & 136.6 & 216.4 \\
14 & 299.0 & 744.7 \\
15 & 170.0 & 523.7 \\
16 & 179.8 & 166.5 \\
17 & 160.5 & 260.8 \\
18 & 151.1 & 153.1 \\
19 & 155.9 & 220.2 \\
20 & 163.8 & 175.0 \\
21 & 124.1 & 141.9 \\
22 & 145.6 & 161.4 \\
23 & 140.0 & 164.4 \\
24 & 190.3 & 179.9 \\
25 & 174.2 & 149.0 \\
26 & 103.7 & 169.3 \\
27 & 184.3 & 225.2 \\
\hline Mean & 173.6 & 220.2 \\
SDa & 37.9 & 127.0 \\
RSD & 21.9 & 57.5 \\
\hline
\end{tabular}

a $\mathrm{SD}=$ standard deviation, ${ }^{\mathrm{b}}$ RSD = relative standard deviation $(\%)$.

Table 1. Liver zinc concentration in samples of fresh and deparaffinized bovine liver tissue.

\section{Discussion}

Zinc is an essential trace element to human health. It plays an important role in membrane stabilization and in cell protection against oxidative stress because it is part of structure of superoxide dismutase, the main enzyme in endogenous control of some types of free oxygen radicals. It also inhibits transition metals, such as copper and iron, from producing reactive types of oxygen (Powell, 2000). This metal is also essential for DNA and RNA polymerase, which has an important effect in hepatic regeneration (Sato et al., 2005).

The liver is one of the main organs in the metabolism of zinc. Disorders in zinc metabolism have been described in patients with chronic liver disease, and several studies found a decrease in plasma, serum or liver zinc concentrations (Loguercio et al., 2001; Halifeoglu et al., Schneider et al., 2009; Matsuoka et al., 2009, Milman et al., 1986; Göksu \& Özsoylu, 1986; Sharda \& Bhandari, 1986; Bode et al., 1988; Kollmeier et al., 1992). The decrease of zinc in liver disease seems to be associated with decreased intake, poor absorption associated with portal hypertension, and greater urinary excretion (Loguercio et al., 2001). Collagenase is a zinc-metalloenzyme and zinc is the most effective inhibitor for prolylhydroxylase, an 
enzyme which plays a key role in collagen synthesis. These two assumptions could explain the role of zinc in collagen deposition and reabsorption in liver disease, the role played by zinc in liver fibrosis and in the evolution of chronic hepatitis toward cirrhosis (Faa et al., 2008).

Some reports found an increase in liver zinc concentrations in chronic liver disease. An increase in copper and zinc liver concentrations was found in Canadian children with chronic cholestasis (Phillips et al., 1996). Another case report described the increase in zinc concentration in hepatic tissue of a child with hepatosplenomegaly and symptoms of zinc deficiency, and the authors speculated about the existence of a zinc metabolism disorder (Sampson et al., 1997). A study that investigated the concentration of metals in liver tissue of adults with hereditary hemochromatosis found an increase in zinc in the liver parenchyma. The authors suggested that the concurrent increase in iron and zinc might be explained by the greater intestinal absorption of these metals (Adams et al., 1991).

The test usually conducted to determine body zinc is the measurement of plasma zinc concentration. However, plasma zinc concentrations do not seem to reflect the concentration found in the liver parenchyma (Göksu \& Özsoylu, 1986; Sato et al., 2005). This may be explained by the fact that there are very efficient homeostatic mechanisms to correct plasma or serum zinc deficiencies, which makes it difficult to diagnose marginal deficiency by using this method. Therefore, the investigation of zinc concentration in liver tissue is important.

Studies report a great variation in liver zinc concentrations, maybe due to the different techniques used (Table 2). Kollmeier et al. (1992) studied the distribution of zinc in adult liver parenchyma from necropsy material, and found a small variation in intraorgan metal concentrations. They reported that zinc concentrations in the liver do not seem to be associated with sex or age (Kollmeier et al., 1992). Another study, conducted with children by Coni et al. (1996), confirmed these findings. They measured the concentration of metal in necropsy material from infants that died of sudden infant death syndrome and from pediatric control subjects, and found that a small liver sample is representative of liver concentration in the whole liver.

\begin{tabular}{lll}
\hline Author and year & Subjects and technique & $\begin{array}{l}\text { Zinc concentration in liver tissues } \\
(\mu \mathrm{g} / \mathrm{g} \text { dry tissue })\end{array}$ \\
\hline Adams et al. (1991) & $\begin{array}{l}\text { Healthy controls }(\mathrm{n}=21) \\
\text { Flame AAS }\end{array}$ & $326.3 \pm 65.4$ \\
Kollmeier et al. (1992) & $\begin{array}{l}\text { Unselected necropsies }(\mathrm{n}=58) \\
\text { Flameless AAS }\end{array}$ & $280.0 \pm 178.0$ \\
Bush et al. (1995) & $\begin{array}{l}\text { Unselected necropsies ( } \mathrm{n}=30) \\
\text { ICP-ESb AAS }\end{array}$ & $191.0 \pm 56.3$ \\
Treble et al. (1998) & $\begin{array}{l}\text { Unselected necropsies ( } \mathrm{n}=73) \\
\text { Graphite furnace AAS }\end{array}$ & $118.3 \pm 44.4$ \\
Hatano et al. (2000) & $\begin{array}{l}\text { Healthy controls (n=21) } \\
\text { Particle-induced X-ray emission }\end{array}$ & $281.0 \pm 25.5$ \\
\hline
\end{tabular}

a AAS = atomic absorption spectrophotometry.

b ICP-ES = inductively coupled plasma emission spectroscopy.

Table 2. Zinc concentration in hepatic tissue according to the literature. 
Fresh tissue is not always available for chemical analysis, but formalin-fixed tissue often is. In our study, zinc concentration measurements in fresh liver tissue and deparaffinized tissue have been shown to be concordant. We have found in fresh e deparaffinized tissues respectively, $173,6 \pm 37,9 \mu \mathrm{g} / \mathrm{g}$ dry weight and $220,2 \pm 127 \mu \mathrm{g} / \mathrm{g}$ dry weight. Two deparaffinized tissue samples showed higher values of zinc than the others samples, causing a higher standard deviation. There was no evidence of mineral contamination during the embedding process to account for these divergent values.

We found only one study in the literature, conducted at the Mayo Clinic by Bush et al. (1995) that compared zinc concentration in fresh and deparaffinized liver tissue. Their study investigated the concentration of metals in several organs using material obtained from autopsy of 30 presumably healthy individuals. Zinc concentration found in fresh liver tissue was $191 \pm 56.3 \mu \mathrm{g} / \mathrm{g}$ dry weight, and, in formalin-fixed tissue, $204 \pm 63.2 \mu \mathrm{g} / \mathrm{g}$ dry weight. They concluded that formalin fixation long-term storage has little effect on zinc concentrations in tissue and that zinc was homogeneously distributed in liver.

Due to the clinical importance of zinc in liver diseases, the use of paraffin-embedded specimens for analysis is extremely useful when fresh tissue is not available. Stored material for analysis may be available even years after the biopsy or autopsy sample was obtained.

\subsection{Conclusion}

More than the results themselves, the proposed protocol for paraffinization/deparaffinization as well as for sample preparation for zinc determination by atomic spectroscopy in paraffinized samples were adequately established. According to the results of this study, paraffin embedding and deparaffinization do not significantly affect the determination of zinc concentrations in liver tissue, and, therefore, stored material can be used for analysis.

\section{Glossary}

AAS - Atomic Absorption Spectrophotometry.

ANVISA - Agência Nacional de Vigilância Sanitária (Sanitary Surveillance National Agency).

FDA - Food and Drug Administration.

ICH - International Conference on Harmonisation of Technical Requirements for Registration of Pharmaceuticals for Human Use.

\section{Acknowledgements}

We are grateful to Coordenação de Aperfeiçoamento de Pessoal de Nível Superior (CAPES), Conselho Nacional de Desenvolvimento Científico e Tecnológico (CNPq) and Fundo de Incentivo a Pesquisas - Hospital de Clínicas de Porto Alegre (FIPE-HCPA).

\section{References}

Adams PC, Bradley C, Frei JV. Hepatic zinc in hemochromatosis. Clin Invest Med.1991;14:16-20. 
Adams PC, Bradley C, Frei JV. Hepatic iron and zinc after portocaval shunting for nonalcoholic cirrhosis. Hepatology. 1994; 19(1):101-105.

ANVISA - Agência Nacional de Vigilância Sanitária. Guidelines for validation of analytical and bioanalytical methods. Diário Oficial da União, Brasília, 2003.

Bayliss EA, Hambidge KM, Sokol RJ, et al. Hepatic concentrations of zinc, copper and manganese in infants with extrahepatic biliary atresia. J Trace Elem Med Biol 1995; 9:40-43.

Beilby JP, Prins AW, Swanson NR. Determination of hepatic iron concentration in fresh and paraffin-embedded tissue. Clin Chem 1999; 45(4):573-574.

Bhardwaj S, Miglani N, Gupta BD, et al. Hepatic zinc levels in Indian childhood cirrhosis. Indian J Med Res 1980; 71:278-281.

Bode JC, Hanisch P, Henning H, et al. Hepatic zinc content in patients with various stages of alcoholic liver disease and in patients with chronic active and chronic hepatitis. Hepatology 1988; 8:1605-1609.

Bush VJ, Moyer TP, Batts KP, et al. Essential and toxic element concentrations in fresh and formalin-fixed human autopsy tissue. Clin Chem 1995; 41:284-294.

Coni P, Ravarino A, Farci AM, et al. Zinc content and distribution in the newborn liver. J Pediatr Gastroenterol Nutr 1996; 23:125-129.

Faa G, Nurchi VM, Ravamino A, et al. Zinc in gastrointestinal and liver disease. Coordination Chem Rev 2008; 252:1257-1269

Fröelich PE, Pinto RB, Wortmann AC, et al. Full validation of an electrothermal atomic absorption for zinc in hepatic tissue using a fast sample preparation procedure. Spectroscopy 2006; 20:81-87.

Göksu, N, Özsoylu S. Hepatic and serum levels of zinc, copper and magnesium in childhood cirrhosis J Pediatr Gastroenterol Nutr 1986; 5:459-462.

Gür G, Bayraktar Y, Ozer D, et al. Determination of hepatic zinc content in chronic liver disease due to hepatitis B virus. Hepatogastroenterology 1998; 45:472-476.

Hambidge M. Human zinc deficiency. J Nutr 2000; 130:1344-1349.

Hamed SA, Hamed EA, Farghaly MH, et al. Trace elements and flapping tremors in patients with liver cirrhosis. Is there a relationship? Saudi Med J. 2008; 29(3):345-351.

Halifeoglu I, Gur B, Aydin S, et al. Plasma trace elements, vitamin B12, folate, and homocysteine levels in cirrhotic patients compared to healthy controls. Biochemistry (Mosc) 2004; 69(6):693-696.

Hatano R, Ebara M, Fukuda H, et al. Accumulation of copper in the liver and hepatic injury in chronic hepatitis C. J Gastroenterol Hepatol 2000; 15:786-791.

ICH - Harmonized Tripartite Guideline, Test on Validation of Analytical Procedures Q2(R1). In: International Conference on Harmonisation of Technical Requirements for Registration of Pharmaceuticals for Human Use, 2005.

Kollmeier H, Seemann J, Wittig P, et al. Zinc concentrations in human tissues. Liver zinc in carcinoma and severe liver disease. Pathol Res Pract 1992; 188:942-945.

Kruse-Jarres JD. Pathogenesis and symptoms of zinc deficiency. Am Clin Lab 2001; 20:17-22.

Loguercio C, De Girolamo V, Federico A, et al. Trace elements and chronic liver diseases. J Trace Elem Med Biol 2001; 11:158-161.

Matsuoka S, Matsumura H, Nakamura $\mathrm{H}$, et al. Zinc supplementation improves the outcome of chronic hepatitis C and liver cirrhosis. J Clin Biochem Nutr 2009; 25:292-303. 
Milman N, Laursen J, Podenphant, et al. Trace elements in normal and cirrhotic human liver tissue. I. Iron, copper, zinc, selenium, manganese, titanium and lead measured by X-ray fluorescence spectrometry. Liver 1986; 6:111-117.

Olynyk JK, O'Neill R, Britton RS, et al. Determination of hepatic iron concentration in fresh and paraffin-embedded tissue: diagnostic implications. Gastroenterology 1994; 106:674-677.

Pereira TC, Saron ML. Carvalho WA, et al. Research on zinc blood levels and nutritional status in adolescents with autoimmune hepatitis. Arq Gastroenterol 2011; 48(1):6265.

Pietrangelo A. Haemochromatosis. Gut 2003; 52 Suppl 2:ii23-ii30

Phillips MJ, Ackerley CA, Superina RA, et al. Excess zinc associated with severe progressive cholestasis in Cree and Ojibwa-Cree children. Lancet 1996; 347:866-868.

Powell SR. The antioxidant properties of zinc. J Nutr 2000; 130:1447-54.

Roberts EA, Schilsky ML. A practice guideline on Wilson disease. Hepatology 2003; 37:14751492.

Rodriguez-Moreno F, González-Reimers E, Santolaria-Fernandez F, et al. Zinc, copper, manganese and iron in chronic alcoholic liver disease. Alcohol 1997; 14:39-44.

Sampson B, Kovar IZ, Rauscher A, et al. A case of hyperzincemia with functional zinc depletion: a new disorder? Pediatr Res 1997; 42:219-225.

Sato C, Koyama H, Satoh H, et al. Concentrations of copper and zinc in liver and serum samples in biliary atresia patients at different stages of traditional surgeries. Tohoku J Exp Med 2005; 207:271-277.

Schneider AC, Pinto RB, Fröelich PE et al. Low plasma zinc concentrations in patients with cirrhosis. J Pediatr (Rio J). 2009; 85(4):359-364.

Sharda B, Bhandari B. Studies of trace elements in childhood cirrhosis. Acta Pharmacol Toxicol (Copenh) 1986; 59 Suppl 7:206-10.

Treble RG, Thompson TS, Lynch HR. Determination of copper, manganese and zinc in human liver. Biometals 1998; 11:49-53.

U.S., Department of Health and Human Services. Food and Drug Administration. Guidance for industry: bioanalytical method validation. Available at: http:/ / www.fda.gov/CDER/GUIDANCE/4252fnl.htm. Accessed: June 30, 2011.

Wortmann AC, Froehlich PE, Pinto RB, et al. Hepatic iron quantification by atomic absorption spectrophotometry: Full validation of an analytical method using a fast sample preparation. Spectroscopy 2007; 21:161-167. 


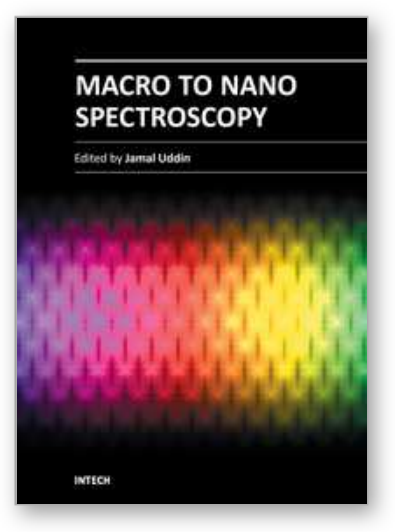

\author{
Macro To Nano Spectroscopy \\ Edited by Dr. Jamal Uddin
}

ISBN 978-953-51-0664-7

Hard cover, 448 pages

Publisher InTech

Published online 29, June, 2012

Published in print edition June, 2012

In the last few decades, Spectroscopy and its application dramatically diverted science in the direction of brand new era. This book reports on recent progress in spectroscopic technologies, theory and applications of advanced spectroscopy. In this book, we (INTECH publisher, editor and authors) have invested a lot of effort to include 20 most advanced spectroscopy chapters. We would like to invite all spectroscopy scientists to read and share the knowledge and contents of this book. The textbook is written by international scientists with expertise in Chemistry, Biochemistry, Physics, Biology and Nanotechnology many of which are active in research. We hope that the textbook will enhance the knowledge of scientists in the complexities of some spectroscopic approaches; it will stimulate both professionals and students to dedicate part of their future research in understanding relevant mechanisms and applications of chemistry, physics and material sciences.

\title{
How to reference
}

In order to correctly reference this scholarly work, feel free to copy and paste the following:

Raquel Borges Pinto, Pedro Eduardo Fröehlich, Ana Cláudia Reis Schneider, André Castagna Wortmann, Tiago Muller Weber and Themis Reverbel da Silveira (2012). An Assay for Determination of Hepatic Zinc by AAS - Comparison of Fresh and Deparaffinized Tissue, Macro To Nano Spectroscopy, Dr. Jamal Uddin (Ed.), ISBN: 978-953-51-0664-7, InTech, Available from: http://www.intechopen.com/books/macro-to-nanospectroscopy/determination-of-zinc-concentration-on-bovine-hepatic-tissue-by-atomic-absorptionspectroscopy-c

\section{INTECH}

open science | open minds

\section{InTech Europe}

University Campus STeP Ri

Slavka Krautzeka 83/A

51000 Rijeka, Croatia

Phone: +385 (51) 770447

Fax: +385 (51) 686166

www.intechopen.com

\section{InTech China}

Unit 405, Office Block, Hotel Equatorial Shanghai

No.65, Yan An Road (West), Shanghai, 200040, China

中国上海市延安西路65号上海国际贵都大饭店办公楼405单元

Phone: +86-21-62489820

Fax: $+86-21-62489821$ 
(C) 2012 The Author(s). Licensee IntechOpen. This is an open access article distributed under the terms of the Creative Commons Attribution 3.0 License, which permits unrestricted use, distribution, and reproduction in any medium, provided the original work is properly cited. 